\title{
Peter Marshall, Demanding the Impossible: A History of Anarchism (Oakland: PM Press, 2010).
}

Peter Marshall's Demanding the Impossible: A History of Anarchism is a well-researched and in-depth study of the history of anarchist thought and practice, written not only to demonstrate the existence of a "profound anarchist tradition" but also to show that this political philosophy "offers many ideas and values that are relevant to contemporary problems and issues." (xiii) The breadth of the book is impressive. Marshall begins with the Taoists of ancient China and ends with contemporary forms of anarchism such as the green anarchists of the late twentieth century. In Demanding the Impossible, Marshall outlines the key tenets of anarchist philosophy, traces the history of European and American libertarian thought, and discusses the theorists who tend to populate the anarchist canon such as Godwin, Stirner, Proudhon, Bakunin, Kropotkin, Tolstoy, and a few others - Reclus, Malatesta, and Goldman — who usually do not make the cut. Marshall then proceeds to explore the anarchist movements in Europe, the United States, Asia, and Latin America, and explores the continual development of anarchist thought in the second half of the twentieth century from Paul Goodman to John Zerzan.

Marshall identifies himself as an anarchist and his enthusiasm for the material is more than apparent. However, there are some serious flaws with Demanding the Impossible. The first stems from Marshall's very broad definition of anarchism. According to the author an anarchist is “... one who rejects all forms of external government and the State and believes that society and individuals would function well without them", which reads more like a definition of libertarianism than anarchism. (xiii) As a result of such a sweeping definition, some very strange individuals fall under the anarchist umbrella — for example, the so-called "anarcho-capitalists" who believe the state is a hindrance to free market capitalism and that all public services and spaces should be privatised. (559) Given Marshall's own conviction that such a society would be no less exploitative than our present day world, and one's own sense that capitalist societies are going in this direction without in any way embodying the other ideals of anarchism, the reader is left to wonder about the coherence and usability of his underlying conceptualisation of his subject.

Yet another odd inclusion in the book, and there are many, is Albert Camus. Camus's link to anarchism is so tenuous as to be almost non-existent. He may have left the French Communist Party and trumpeted rebellion and syndicalism in The Rebel but so what? Camus was a French nationalist and an apologist for French colonialism in Algeria by any means necessary, hardly an anarchist position, a fact that Marshall openly admits. Nor did Camus proclaim himself an anarchist. So why include him?

Marshall would have been better served to define anarchism more clearly at the outset of Demanding the Impossible. Had he defined the term more closely 
-as a leftwing political philosophy that is not only against the state and government, but for the freedom of individuals who in turn respect the freedom of others; not only against hierarchy and capitalism, but for a society of free producers- there would have been no need to include such questionable figures and tendencies. It might have made more sense for Marshall to write two books — one on anarchism proper, and another on libertarianism, in all its left- and right-wing permutations and combinations.

A second problem with Demanding the Impossible, and this is a problem of most general histories of anarchism, is its focus on Europe and the United States. In a book of over 700 pages of text, there are roughly thirty pages dedicated to regions outside of Europe and America, those being Latin America and Asia. Part of this problem is due to a lack of English-language sources on the anarchists and their movements in China, Korea, Argentina, and Brazil. In light of the ever increasing number of studies on anarchism and its importance in these typically ignored regions, Marshall could have struck a better balance between Europe and the United States on the one hand and the rest of the world on the other.

As a history of anarchism, Demanding the Impossible is, in many ways, a great improvement over previous works by James Joll and George Woodcock because it treats anarchism as much more than an old millenarian movement that died in Spain in 1939. However, Marshall's broad definition of anarchism, which leads to the inclusion of many individuals who were not anarchists, and his narrow focus on Europe and the United States, will leave many readers scratching their heads - and waiting a far more coherent and international history of the movement.

Travis Tomchuk

Queen's University

\section{Pierre-Arnaud Chouvy, Opium: Uncovering the Politics of the Poppy} (Cambridge: Harvard University Press, 2010).

Despite almost 100 years of US-led opium prohibitionist policies, the poppy plant and its drug derivatives have witnessed an explosion of growth. The political and economic factors that led to this increase is the subject of Pierre-Arnaud Chouvy's Opium: Uncovering the Politics of Poppy. He answers important questions about the efficacy of the last 40 years of the War on Drugs. He provides compelling evidence on the failings of policies that are implemented on drug-producing nations. His most convincing arguments detail why programs currently in place (primarily poppy eradication and crop substitution) have proven counter-effective.

Chouvy presents a coherent and detailed narrative on the evolution of Papaver somniferum, the poppy. Before discovery of its soporific effects became apparent, its flower attracted early agriculturalists. The plant thrived for thousands 